\title{
OPTIMALISASI PANJANG JARINGAN PIPA AIR BERSIH DI DKI JAKARTA MENGGUNAKAN MINIMUM SPANNING TREE
}

\author{
Glisina Dwinoor Rembulan*, Julliete Angel Luin, Vri Julianto, Giovandri Septorino \\ Program Studi Teknik Industri, Fakultas Teknologi dan Desain, Universitas Bunda Mulia \\ Email: rembulanglisina@gmail.com; jullieteluin@gmail.com; vrijulianto@gmail.com;
} giovandriseptorino@gmail.com

Artikel masuk : 10-04-2020

Artikel direvisi : 04-06-2020

Artikel diterima : 16-06-2020

*Penulis Korespondensi

\begin{abstract}
Abstrak - Ketahanan air adalah prioritas utama untuk mencapai kedaulatan pangan nasional. Saat ini ketersediaan akses air bersih belum merata. Jaringan pipa air bersih memainkan peran penting untuk menunjang terpenuhinya permintaan air bersih oleh masyarakat. Jaringan pipa air bersih di DKI Jakarta diakomodasi oleh PT Aetra Air Jakarta (AETRA) dan PT PAM Lyonnaise Jaya (PALYJA). Minimum Spanning Tree (MST) merupakan metode yang digunakan untuk meminimalkan biaya yang dikeluarkan dengan mengoptimalkan jarak. Metode MST digunakan untuk mengoptimalkan panjang jaringan pipa air bersih di DKI Jakarta sehingga dapat meminimalkan total biaya. Hasil dari pengolahan data setelah menggunakan metode MST diperoleh panjang minimum dari jaringan pipa air bersih untuk PT Aetra Air Jakarta dan PT PAM Lyonaisse Jaya sehingga mengurangi total biaya yang dikeluarkan. Total biaya PT PAM Lyonaisse Jaya berkurang 2 kali lipat dan PT Aetra Air Jakarta 16 kali lipat lebih rendah dari semula.
\end{abstract}

Kata kunci: Ketahanan Air; Minimum Spanning Tree; PT AETRA; PT PALYJA

\begin{abstract}
Water security is a top priority for achieving national food sovereignty. The present availability of access to clean water is not evenly distributed. Clean water pipelines play an important role to support the fulfillment of the demand for clean water by the community. Clean water pipelines in DKI Jakarta are accommodated by PT Aetra Air Jakarta (AETRA) and PT PAM Lyonnaise Jaya (PALYJA). Minimum Spanning Tree (MST) is a method used to minimize costs incurred by optimizing distance. The MST method is used to optimize the length of clean water pipelines in DKI Jakarta in order to minimize the total cost. The results of data processing after using the MST method obtained the minimum length of clean water pipelines for PT Aetra Air Jakarta and PT PAM Lyonaisse Jaya thereby reducing the total costs incurred. The total cost of PT PAM Lyonaisse Jaya was reduced by 2 times and PT Aetra Air Jakarta 16 times lower than before.
\end{abstract}

Keywords: Water Security; Minimum Spanning Tree; PT AETRA; PT PALYJA 


\section{PENDAHULUAN}

Ketahanan air adalah prioritas utama untuk mencapai kedaulatan pangan nasional. Sekitar 4 miliar orang mengalami kelangkaan air parah selama setidaknya satu bulan dalam setahun (Mekonnen \& Hoekstra, 2016). Penggunaan air telah meningkat di seluruh dunia sekitar $1 \%$ per tahun sejak 1980-an dan diperkirakan akan terus meningkat hingga tahun 2050, terhitung sebesar $20 \%$ hingga $30 \%$ di atas tingkat penggunaan air saat ini (Burek et al., 2016). Tantangan utama yang harus dihadapi saat ini termasuk, air bersih dan sanitasi yang layak, pasokan air baku yang sesuai dengan kebutuhan, eksploitasi air tanah yang masif, kerusakan pada daerah aliran sungai, dan perubahan iklim (Direktorat Jenderal Sumber Daya Air, 2017; Kementerian Pekerjaan Umum dan Perumahan Rakyat, 2015; Kementerian Pekerjaan Umum dan Perumahan Rakyat Direktorat Jenderal Sumber Daya Air, 2019).

Ketersediaan akses air bersih belum merata. Air yang dapat dimanfaatkan sebesar 25,3\% dengan 7,04 $\mathrm{m}^{3} /$ detik kapasitas air baku belum dimanfaatkan (Direktorat Jenderal Sumber Daya Air, 2017; Kementerian Pekerjaan Umum dan Perumahan Rakyat, 2015). Hingga akhir 2018, ketersediaan akses air bersih baru mencapai $72 \%$, dengan Pulau Jawa sebesar 6,3\% (detikFinance, 2019; Direktorat Jenderal Sumber Daya Air, 2017; Fikri, 2018; indonesia.go.id, 2019). DKI Jakarta memiliki kebutuhan air mencapai $28 \mathrm{~m}^{3}$ sedangkan air bersih yang tersedia hanya $18 \mathrm{~m}^{3}$ (Brata, 2018; Guritno, 2019; Iqbal, 2019).

Jaringan pipa air bersih memainkan peran penting untuk menunjang terpenuhinya permintaan air bersih oleh masyarakat. Sistem distribusi air bersih adalah jaringan perpipaan yang terdiri dari sistem perpipaan, pompa, reservoir, dan peralatan lainnya (Adrian, Syahrizal, \& Indrawan, 2014; Setyono \& Prayogo, 2018). Sampai dengan saat ini telah dibangun jaringan air baku dengan kapasitas layanan $51,44 \mathrm{~m}^{3}$ /detik, yang belum memenuhi target kapasitas yang direncanakan (56 $\mathrm{m}^{3} /$ detik) (Direktorat Jenderal Sumber Daya Air, 2017). Pengembangan jaringan pipa air perlu terus ditingkatkan agar semakin banyak warga yang memiliki akses terhadap air bersih (Said, 2019; Sutikno, Rispiningtati, \& Prayogo, 2014).

Total jarak tempuh mempengaruhi biaya yang dikeluarkan. Konstruksi jaringan perpipaan merupakan bagian yang paling mahal dari sistem distribusi air (Al Amin, 2011). Semakin jauh jarak yang ditempuh maka biaya semakin mahal; sebaliknya jarak tempuh yang lebih pendek mengindikasikan biaya yang lebih rendah (Hillier
\& Lieberman, 2010; R Gultom, 2017; Sarjono, 2014; Wulandari \& Arifin, 2018). Penentuan rute yang tepat menghasilkan rute yang efisien dengan biaya yang minimum (Anisah, 2016; Anka, Andrawina, \& Rendra, 2017; Muhammad, Bakhtiar, \& Rahmi, 2017; Pillai, Chick, Johanning, Khorasanchi, \& De Laleu, 2015; Wahyu, Samanhudi, \& Akmal, 2018). Penelitian sebelumnya membahas tentang jaringan pipa untuk meminimalkan panjang jaringan dengan metode heuristik (Nurprihatin, et al., 2019).

Jaringan pipa air bersih di DKI Jakarta diakomodasi oleh PT Aetra Air Jakarta (AETRA) dan PT PAM Lyonnaise Jaya (PALYJA). PT AETRA bertanggung jawab dalam pelayanan air bersih di wilayah Timur DKI Jakarta sedangkan PT PALYJA di wilayah Barat DKI Jakarta (Ikhsanudin, 2019; Kahfi, 2019; PT Aetra Air Jakarta, 2019c; PT PAM Lyonnaise Jaya, 2019b). Kedua perusahaan tersebut melakukan pelayanan air bersih dimulai dari pengolahan air baku menjadi air bersih, mendistribusikannya, melakukan pembacaan meter air, mengelola tagihan air, meningkatkan penyediaan air bersih dan pelayanan kepada masyarakat (Aetra, 2017; Palyja, 2017). Sampai dengan akhir 2018, total jaringan pipa air PT AETRA mencapai $6.275 \mathrm{~km}$ dan PT PALYJA mencapai $5.471 \mathrm{~km}$ (PT Aetra Air Jakarta, 2019b; PT PAM Lyonnaise Jaya, 2019a).

Terdapat berbagai metode yang digunakan untuk mengoptimalkan jarak. Vehicle Routing Problem meminimalkan jarak distribusi, meminimalkan biaya transportasi dan meningkatkan jumlah permintaan (Anka et al., 2017; Chandra \& Setiawan, 2018; SM, Ekawati, \& Febriana, 2017). Transportation Method menghasilkan rute yang optimal (Aqidawati, Rahadian, Haqqoni, Yuniaristanto, \& Sutopo, 2018; Irwan \& Yuniral, 2016; Ridha, Abdi, \& Mahyudin, 2016; M. H. Setiawan, Imrona, \& Murdiansyah, 2017). Selain itu metode Saving Matrix menghasilkan rute yang efisien dan biaya transportasi yang minimum (Addini's \& Fauzan, 2018; Indrawati, Eliyati, \& Lukowi, 2016; Muhammad et al., 2017). Integrasi antara metode transportasi dan Savings Algorithm juga telah dibahas untuk meminimalkan biaya distribusi (Nurprihatin \& Tannady, 2018).

Minimum Spanning Tree (MST) dapat meminimalkan biaya yang dikeluarkan dengan mengoptimalkan jarak. MST dapat diterapkan di bidang transportasi, energi, jaringan komunikasi sampai peningkatan akurasi diagnostik untuk penyakit Alzheimer (Guo, Liu, Chen, Xu, \& Jie, 2017; Li, Mao, Zhang, \& Li, 2016; Mosbah, Arif, Mohammedi, \& Hellal, 2017; Rizki, 2012). Penerapan MST dapat meminimalkan biaya 
pengiriman palung kabel, mebel dan ukiran kayu; mengoptimalkan panjang pipa air bersih dan jaringan distribusi listrik; juga menghemat investasi konfigurasi koneksi kabel pada wind farm pantai (Akpan \& Iwok, 2017; Jono, 2014; Latifah \& Sugiharti, 2015; Peng Hou, Weihao Hu, \& Chen, 2015; Pratama, Sumarno, \& Darmaji, 2013; Riswan, 2018; Wattimena \& Lawalata, 2013).

Penelitian ini meninjau panjang jaringan pipa air bersih dengan metode MST di DKI Jakarta. Metode MST diharapkan dapat mengoptimalkan panjang jaringan pipa air bersih sehingga dapat meminimalkan total biaya.

\section{METODE PENELITIAN}

Penelitian ini dilakukan pada bulan Agustus tahun 2019. Penelitian ini dimulai dengan mengumpulkan data-data yang diperlukan. Adapun data yang diperoleh adalah lokasi sumber air baku, jumlah dan lokasi kecamatan di DKI Jakarta, dan jarak dari sumber air ke tiap-tiap kecamatan. Selanjutnya dilakukan penghitungan jarak optimal dalam pendistribusian air dengan menggunakan metode Minimum Spanning Tree dengan aplikasi QM for Windows, menghitung biaya distribusi air berdasarkan jarak tempuh dari hasil analisa dan menghitung total biaya pendistribusian air..

Objek yang menjadi penelitian ini adalah jaringan pipa air bersih di DKI Jakarta. Pengumpulan data yang dilakukan adalah pengumpulan data sekunder dengan melakukan pencarian di laman resmi PT. Aetra Air Jakarta dan PT. PAM Lyonnaise Jaya (PALYJA). Selain itu, pengumpulan data juga dilakukan dengan bantuan Google Maps untuk mendapatkan data mengenai jarak dari booster pump ke setiap kecamatan di DKI Jakarta.

\section{Graf}

Secara matematis, graf didefinisikan sebagai pasangan antara himpunan tidak kosong dari simpul-simpul (V) dengan sisi-sisi yang menghubungkan sepasang simpul (E). Graf dapat ditulis singkat sebagai $\mathrm{G}=(\mathrm{V}, \mathrm{E})$.

Simpul pada graf dapat menggunakan huruf atau bilangan asli ataupun gabungan keduanya. Sedangkan sisi atau garis yang menghubungkan antar simpul $\mathrm{v}_{\mathrm{i}}$ dengan $\mathrm{v}_{\mathrm{j}}$ dapat dituliskan dengan lambang $e_{1}, e_{2}, \ldots, e_{n}$ sehingga e dapat ditulis $e=\left(v_{i}, v_{j}\right)$ (Munir, 2010). Sisi atau garis pada graf dapat dibedakan menjadi dua jenis berdasarkan orientasi arah (Munir, 2010):

1. Graf tak-berarah (undirected graph)

Graf tak berarah merupakan graf yang sisi atau garisnya tidak memiliki arah. Pada graf ini, urutan pada pasangan simpul yang dihubungkan tidak dipeduli, jadi $(\mathrm{vj}, \mathrm{vk})=(\mathrm{vk}$, vj). Gambar 1 merupakan contoh graf tak berarah.

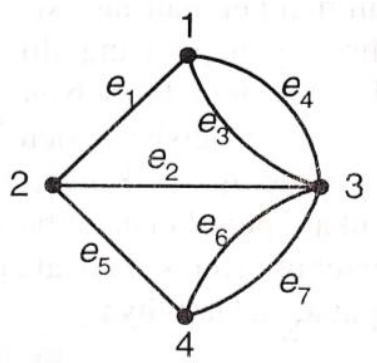

Gambar 1. Graf Tak Berarah

2. Graf berarah (directed graph atau digraph)

Graf berarah adalah graf yang pada setiap sisi atau garisnya memiliki orientasi arah. Sisi atau garis yang berarah dapat disebut juga busur (arc). Pada graf ini, urutan pada pasangan simpul diperhatikan, jadi (vj, vk) $\neq$ (vk, vj). Gambar 2 merupakan contoh graf berarah.

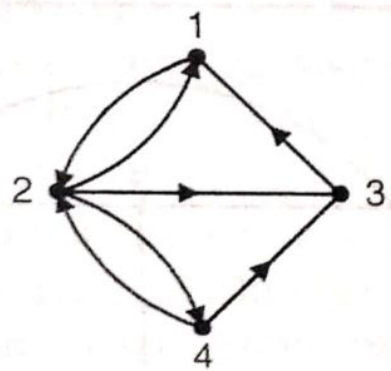

Gambar 2. Graf Berarah

\section{Terminologi Dasar}

Beberapa terminologi dasar yang sering digunakan dalam graf (Munir, 2010):

1. Bertetangga (Adjacent)

Dua buah simpul dikatakan bertetangga bila keduanya terhubung oleh sisi atau garis. Contohnya: pada Gambar 2, simpul 1 dan 2 dihubungkan oleh e1 sehingga dapat dikatakan bertetangga, tetapi simpul 1 dan 4 tidak bertetangga karena tidak ada sisi atau garis yang menghubungkan kedua simpul.

2. Bersisian (Incident)

Sisi e yang menghubungkan simpul vi dan vj akan dikatakan bersisian dengan kedua simpul tersebut. Contohnya: pada Gambar 2, e 5 bersisian dengan simpul 2 dan 4 karena e 5 menghubungkan kedua simpul tersebut.

3. Simpul Terpencil (Isolated Vertex)

Simpul terpencil merupakan simpul yang tidak memiliki sisi yang bersisian atau tidak bertetangga dengan simpul yang lain. 


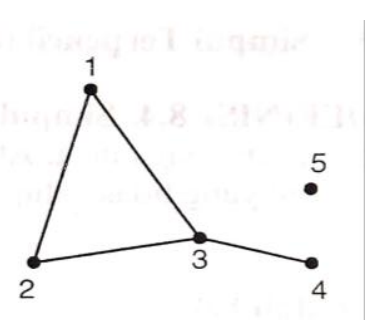

Gambar 3. Graf dengan Simpul Terpencil

Pada gambar 3, simpul 5 merupakan simpul terpencil karena tidak bersisian dengan sisi ataupun tidak bertetangga dengan simpul yang lain.

4. Graf Kosong (Null Graph atau Empty Graph)

Graf kosong adalah graf yang himpunan sisinya merupakan himpunan kosong dan biasanya ditulis sebagai $\mathrm{Nn}$, di mana $\mathrm{n}$ adalah jumlah simpul. Gambar 4 adalah contoh dari simpul terpencil.

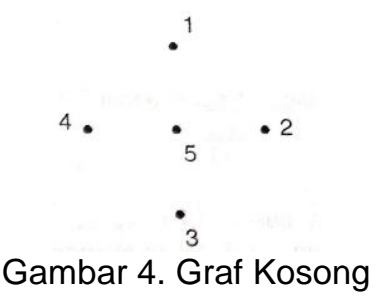

5. Derajat (Degree)

Derajat pada simpul menunjukan jumlah sisi yang bersisian dengan simpul. Contoh pada Gambar $2 \mathrm{~d}(1)=\mathrm{d}(2)=3, \mathrm{~d}(3)=5$.

6. Lintasan (Path)

Panjang dari simpul awal (v0) ke simpul akhir (vn) yang terdiri dari barisan selang seling antara simpul-simpul dan sisi-sisi. Pada Gambar 2, contoh salah satu lintasan adalah $1, \mathrm{e} 1,2, \mathrm{e} 5,4, \mathrm{e} 7,3$.

7. Siklus (Cycle) atau Sirkuit (Circuit)

Siklus atau sirkuit adalah lintasan yang awal dan akhirnya ada pada simpul yang sama. Contoh: pada Gambar 2, terdapat siklus yaitu $1,2,3,1$

8. Terhubung (Connected)

Dua simpul yang terhubung harus memiliki lintasan dari simpul satu ke simpul lainnya. Gambar 5 merupakan contoh graf tak terhubung.

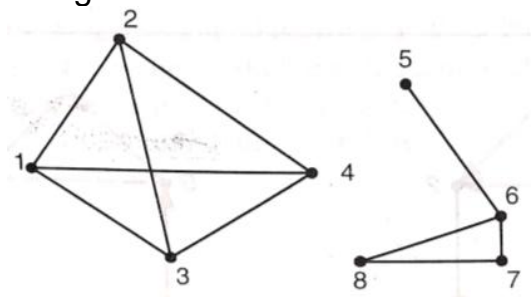

Gambar 5. Graf tak Terhubung
9. Graf Berbobot (Weighted Graph)

Graf berbobot adalah graf yang di setiap sisinya sudah diberi harga (bobot). Bobot di setiap sisinya untuk menyatakan jarak, biaya waktu tempuh, ongkos produksi, dan sebagainya. Gambar 6 adalah contoh dari graf berbobot.

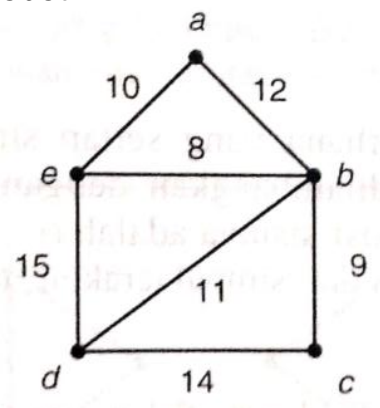

Gambar 6. Graf Berbobot

\section{Algoritma}

Algoritma untuk masalah Minimum Spanning Tree (Hillier \& Lieberman, 2010):

1. Pilih sembarang simpul, dan kemudian sambungkan ke simpul berbeda yang terdekat.

2. Identifikasi node yang tidak terhubung tetapi paling dekat dengan node yang terhubung, kemudian hubungkan dua node tersebut. Ulangi langkah ini sampai semua node telah terhubung.

3. Tie breaking: node yang telah terhubung pada step 1 dan 2 dapat diputuskan sewenangwenangnya dan algoritma tetap harus menghasilkan solusi yang optimal.

\section{HASIL DAN PEMBAHASAN \\ Titik Lokasi Sumber Air Bersih dan Distribusi}

Distribusi air di Jakarta dikelola oleh PT AETRA dan PT PALYJA. Booster pump digunakan untuk mendistribusikan air ke seluruh kecamatan di wilayah DKI Jakarta. PT AETRA mengelola 6 booster pump, yaitu Pompa Tekan Sumur Batu (JI. PAM Sumur Batu Kelurahan Cempaka Baru Jakarta Pusat 10640), Pompa Tekan Halim (JI. Raya Kalimalang, Jakarta Timur), Pompa Tekan Pasar Rebo (JI. Raya Bogor KM. 22 Pasar Rebo, Jakarta Timur 13830), Pompa Tekan Kiwi (Jl. Raya Bogor KM.26 Pasar Rebo, Jakarta Timur), Pompa Tekan Sungai Bambu (Jl. Sungai Bambu Raya Kelurahan Papanggo Jakarta Pusat 10640), dan Pompa Tekan Tugu (Jl. Cakung Cilincing/ Tugu Raya Semper Barat, Jakarta Utara). Sedangkan PT PALYJA mengelola 2 booster pump, yaitu Booster Pump Daan Mogot (Jl. Daan Mogot Flyover No.10, RT.11/RW.2, Kedaung Kali Angke, Kecamatan Cengkareng, Kota Jakarta Barat, Daerah Khusus lbukota Jakarta 11710) 
dan Booster Pump Gedong Panjang (Jl. Pluit Raya No.7, RT.7/RW.9, Penjaringan, Kec. Penjaringan, Kota Jkt Utara, Daerah Khusus Ibukota Jakarta 14440). Air bersih didistribusikan ke Provinsi Jakarta yang terbagi dalam 42 kecamatan, yaitu 8 kecamatan di Jakarta Pusat, 6 kecamatan di Jakarta Utara, 8 kecamatan di Jakarta Barat, 10 kecamatan di Jakarta Selatan, dan 10 kecamatan di Jakarta Timur.
Jarak dari Sumber Air ke Tiap-tiap Kecamatan PT AETRA dan PT PALYJA bertanggung jawab menyalurkan air secara merata di DKI Jakarta. PT AETRA bertanggungjawab di daerah Jakarta Timur (tabel 1) dan sebagian wilayah Jakarta Utara dan Pusat (Tabel 2). PT PALYJA bertanggung jawab di daerah Jakarta Selatan (tabel 3), Jakarta Barat (Tabel 4) dan sebagian wilayah Jakarta Utara dan Pusat (tabel 5).

Tabel 1. Jarak antar Booster Pump ke Kecamatan Wilayah Jakarta Timur PT AETRA (Kilometer)

\begin{tabular}{|c|c|c|c|c|c|c|c|c|c|c|}
\hline \multirow{2}{*}{$\begin{array}{c}\text { PT AETRA AIR } \\
\text { JAKARTA } \\
\text { Kecamatan }\end{array}$} & \multicolumn{10}{|c|}{ Jakarta Timur } \\
\hline & Cakung & Cipayung & Ciracas & $\begin{array}{l}\text { Duren } \\
\text { Sawit }\end{array}$ & $\begin{array}{c}\text { Jati } \\
\text { negara }\end{array}$ & $\underset{\text { Jati }}{\text { Kramat }}$ & Makasar & Matraman & $\begin{array}{l}\text { Pasar } \\
\text { Rebo }\end{array}$ & $\begin{array}{l}\text { Pulo } \\
\text { Gadung }\end{array}$ \\
\hline $\begin{array}{l}\text { Pompa Tekan } \\
\text { Pasar Rebo }\end{array}$ & 26 & 8,5 & 4,6 & 16 & 12 & 4,4 & 9,8 & 16 & 3,5 & 18 \\
\hline $\begin{array}{l}\text { Pompa Tekan } \\
\text { Pump Kiwi }\end{array}$ & 29 & 5,5 & 2 & 19 & 16 & 8 & 13 & 19 & 2,3 & 22 \\
\hline $\begin{array}{l}\text { Pompa Tekan } \\
\text { Halim }\end{array}$ & 17 & 14 & 15 & 5,9 & 2,4 & 6,1 & 8,4 & 6 & 13 & 8,5 \\
\hline $\begin{array}{l}\text { Pompa Tekan } \\
\text { Pump Tugu }\end{array}$ & 9,8 & 32 & 32 & 20 & 20 & 25 & 26 & 15 & 31 & 11 \\
\hline $\begin{array}{l}\text { Pompa Tekan } \\
\text { Sumur Batu }\end{array}$ & 10 & 24 & 23 & 14 & 11 & 17 & 18 & 8,3 & 24 & 6,5 \\
\hline $\begin{array}{l}\text { Pompa Tekan } \\
\text { Sungai Bambu }\end{array}$ & 17 & 30 & 31 & 20 & 17 & 27 & 25 & 14 & 30 & 13 \\
\hline
\end{tabular}

Tabel 2. Jarak antar Booster Pump ke Kecamatan Wilayah Jakarta Utara dan Jakarta Pusat PT AETRA (Kilometer)

\begin{tabular}{lcccccc}
\hline \begin{tabular}{c} 
PT AETRA AIR JAKARTA \\
\multicolumn{1}{c}{ Kecamatan }
\end{tabular} & \multicolumn{3}{c}{ Jakarta Utara } & \multicolumn{4}{c}{ Jakarta Pusat } \\
Pademangan & Tanjung Priok & Cempaka Putih & Johor Baru & Kemayoran & Sawah Besar \\
\hline Pompa Tekan Pasar Rebo & 26 & 25 & 16 & 17 & 21 & 20 \\
& 29 & 28 & 19 & 21 & 24 & 24 \\
Pompa Tekan Pump Kiwi & & & & & & 15 \\
Pompa Tekan Halim & 17 & 15 & 7,6 & 8,6 & 12 & 15 \\
Pompa Tekan Pump Tugu & 12 & 12 & 14 & 13 & 14 & 14 \\
Pompa Tekan Sumur Batu & 8 & 6,3 & 4,4 & 5,4 & 4,5 & 6,4 \\
Pompa Tekan Sungai Bambu & 7,1 & 2,1 & 12 & 13 & 14 & 11 \\
\hline
\end{tabular}


Tabel 3. Jarak antar Booster Pump ke Kecamatan Wilayah Jakarta Selatan PT PT PALYJA (Kilometer)

\begin{tabular}{|c|c|c|c|c|c|c|c|c|c|c|}
\hline \multirow{2}{*}{$\begin{array}{c}\text { PT PAM } \\
\text { LYONAISSE } \\
\text { JAYA } \\
\text { Kecamatan }\end{array}$} & \multicolumn{10}{|c|}{ Jakarta Selatan } \\
\hline & Cilandak & $\begin{array}{c}\text { Jaga } \\
\text { karsa }\end{array}$ & $\begin{array}{c}\text { Kebayoran } \\
\text { Baru }\end{array}$ & $\begin{array}{c}\text { Kebayoran } \\
\text { Lama }\end{array}$ & $\begin{array}{c}\text { Mampang } \\
\text { Prapatan }\end{array}$ & Pancoran & $\begin{array}{c}\text { Pasar } \\
\text { Minggu }\end{array}$ & $\begin{array}{c}\text { Pesangg } \\
\text { rahan }\end{array}$ & $\begin{array}{l}\text { Setia } \\
\text { Budi }\end{array}$ & Tebet \\
\hline $\begin{array}{l}\text { Booster } \\
\text { Pump Daan } \\
\text { Mogot }\end{array}$ & 22 & 31 & 11 & 20 & 21 & 23 & 27 & 17 & 14 & 22 \\
\hline $\begin{array}{l}\text { Booster } \\
\text { Pump } \\
\text { Gedong } \\
\text { Panjang } \\
\end{array}$ & 30 & 30 & 17 & 22 & 18 & 20 & 26 & 25 & 11 & 19 \\
\hline
\end{tabular}

Tabel 4. Jarak antar Booster Pump ke Kecamatan Wilayah Jakarta Barat PT PT PALYJA (Kilometer)

\begin{tabular}{lcccccccc}
\hline $\begin{array}{c}\text { PT PAM } \\
\text { LYONAISSE } \\
\text { JAYA }\end{array}$ & Cengkareng & $\begin{array}{c}\text { Grogol } \\
\text { Petamburan }\end{array}$ & $\begin{array}{c}\text { Taman } \\
\text { Sari }\end{array}$ & Tambora & $\begin{array}{c}\text { Kebon } \\
\text { Jeruk }\end{array}$ & $\begin{array}{c}\text { Kali } \\
\text { deres }\end{array}$ & Palmerah Kembangan \\
\hline $\begin{array}{l}\text { Booster Pump } \\
\text { Daan Mogot } \\
\text { Booster Pump } \\
\text { Gedong }\end{array}$ & 5,9 & 4,9 & 9,4 & 8,2 & 6,1 & 8,9 & 7,5 & 8,6 \\
Panjang & 12 & 8,1 & 2 & 3,2 & 14 & 17 & 14 & 15 \\
\hline
\end{tabular}

Tabel 5. Jarak antar Booster Pump ke Kecamatan Wilayah Jakarta Pusat da Jakarta Utara PT PT PALYJA (Kilometer)

\begin{tabular}{|c|c|c|c|c|c|c|c|c|}
\hline \multirow{2}{*}{$\begin{array}{c}\text { PT PAM } \\
\text { LYONAISSE JAYA } \\
\text { Kecamatan }\end{array}$} & \multicolumn{4}{|c|}{ Jakarta Pusat } & \multicolumn{4}{|c|}{ Jakarta Utara } \\
\hline & Gambir & Menteng & Senen & $\begin{array}{l}\text { Tanah } \\
\text { Abang }\end{array}$ & Clincing & $\begin{array}{l}\text { Kelapa } \\
\text { Gading }\end{array}$ & Koja & Penjaringan \\
\hline $\begin{array}{l}\text { Booster Pump } \\
\text { Daan Mogot }\end{array}$ & 11 & 15 & 14 & 12 & 27 & 24 & 23 & 8,3 \\
\hline $\begin{array}{l}\text { Booster Pump } \\
\text { Gedong Panjang }\end{array}$ & 7,7 & 12 & 12 & 14 & 19 & 17 & 15 & 1,4 \\
\hline
\end{tabular}

\section{Pengolahan Data dengan QM for Windows}

Biaya transportasi juga didekati dengan waktu tempuh yang tidak tetap meskipun jarak tempuh tidak berubah (Nurprihatin, Elnathan, Rumawan, \& Regina, 2019). Biaya transportasi juga diminimalkan dengan Fuzzy Analytical Network Process (FANP) (Rembulan \& Nurprihatin, 2019). Penelitian - penelitian terdahulu hanya mengulas segi jarak atau segi biaya saja dari jaringan pipa airs (Arifuddin, Parung, \& Thaha, 2013; Hidayah, Andawayanti, \& Lufira, 2020; H. D. Setiawan, Haribowo, \& Ismoyo, 2019; Windarto \& Sudirman, 2018). Perhitungan Minimum Spanning Tree dilakukan menggunakan aplikasi $Q M$ for Windows dengan memasukan seluruh data jarak antar booster pump ke setiap kecamatan dalam wilayah PT AETRA dan PT PALYJA secara terpisah. Kedua perusahaan tersebut menggunakan pipa berbahan HDPE (High-density Polyethylene) dengan diameter 0.5 inci (Kadir, 2020; PT Aetra Air Jakarta, 2019a). Booster pump adalah start node, sedangkan kecamatan adalah end node. Hasil dari pengolahan data kemudian dikalikan dengan biaya pipa HDPE (Rp. 7.000.000/ km) untuk menghasilkan biaya total (CV. Aneka Pratama, 2020).

Berdasarkan hasil pengolahan data yang dilakukan, diperoleh kesimpulan bahwa biaya yang dapat dipotong dengan meminimalkan jarak untuk PT PAM Lyonaisse Jaya berkurang sebanyak 2 kali lipat dari semula. Sedangkan 
biaya yang dikeluarkan PT AETRA Air Jakarta menjadi 16 kali lipat lebih rendah dari semula. Hasil Tujuan setiap booster pump dapat dirampingkan seperti pada Tabel 6 dan 7. Melalui Gambar 7 dan 8, dapat dilihat distribusi tiap tiap booster pump ke tiap - tiap kecamatan setelah diolah menggunakan Minimum Spanning Tree.

Tabel 6. Hasil Perampingan Jarak Booster Pump ke Kecamatan PT PALYJA

\begin{tabular}{cccc}
\hline $\begin{array}{c}\text { Branch } \\
\text { Name }\end{array}$ & $\begin{array}{c}\text { Start } \\
\text { Node }\end{array}$ & $\begin{array}{c}\text { End } \\
\text { Node }\end{array}$ & $\begin{array}{c}\text { Distance } \\
(\text { Km })\end{array}$ \\
\hline Branch 1 & 1 & 3 & 22 \\
Branch 3 & 1 & 5 & 11 \\
Branch 4 & 1 & 6 & 20 \\
Branch 8 & 1 & 10 & 17 \\
Branch 11 & 1 & 13 & 5,9 \\
Branch 12 & 1 & 14 & 4,9 \\
Branch 15 & 1 & 17 & 6,1 \\
Branch 16 & 1 & 18 & 8,9 \\
Branch 17 & 1 & 19 & 7,5 \\
Branch 18 & 1 & 20 & 8,6 \\
Branch 22 & 1 & 24 & 12 \\
Branch 28 & 2 & 4 & 30 \\
Branch 31 & 2 & 7 & 18 \\
Branch 32 & 2 & 8 & 20 \\
Branch 33 & 2 & 9 & 26 \\
Branch 35 & 2 & 11 & 11 \\
Branch 36 & 2 & 12 & 19 \\
Branch 39 & 2 & 15 & 2 \\
Branch 40 & 2 & 16 & 3,2 \\
Branch 45 & 2 & 21 & 7,7 \\
Branch 46 & 2 & 22 & 12 \\
Branch 47 & 2 & 23 & 12 \\
Branch 49 & 2 & 25 & 19 \\
Branch 50 & 2 & 26 & 17 \\
Branch 51 & 2 & 27 & 15 \\
Branch 52 & 2 & 28 & 1,4 \\
\hline Total Distance $\mathbf{( K m ) ~}$ & & 337,2 \\
Total Cost (Rp) & & 2.360 .400 .000 \\
\hline
\end{tabular}

Tabel 7. Hasil Perampingan Jarak Booster Pump ke Kecamatan PT AETRA

\begin{tabular}{cccc}
\hline $\begin{array}{c}\text { Branch } \\
\text { Name }\end{array}$ & $\begin{array}{c}\text { Start } \\
\text { Node }\end{array}$ & $\begin{array}{c}\text { End } \\
\text { Node }\end{array}$ & $\begin{array}{c}\text { Distance } \\
(\mathbf{K m})\end{array}$ \\
\hline Branch 6 & 1 & 12 & 4,4 \\
Branch 9 & 1 & 15 & 3,5 \\
Branch 18 & 2 & 8 & 5,5 \\
Branch 19 & 2 & 9 & 2 \\
Branch 25 & 2 & 15 & 2,3 \\
Branch 36 & 3 & 10 & 5,9 \\
Branch 37 & 3 & 11 & 2,4 \\
Branch 39 & 3 & 13 & 8,4 \\
Branch 40 & 3 & 14 & 6 \\
Branch 49 & 4 & 7 & 9,8 \\
Branch 74 & 5 & 16 & 6,5 \\
Branch 77 & 5 & 19 & 4,4 \\
Branch 78 & 5 & 20 & 5,4 \\
Branch 79 & 5 & 21 & 4,5 \\
Branch 80 & 5 & 22 & 6,4 \\
Branch 91 & 6 & 17 & 7,1 \\
Branch 92 & 6 & 18 & 2,1 \\
\hline Total Distance (Km) & & 86,6 \\
Total Cost (Rp) & & 606.200 .000 \\
\hline
\end{tabular}

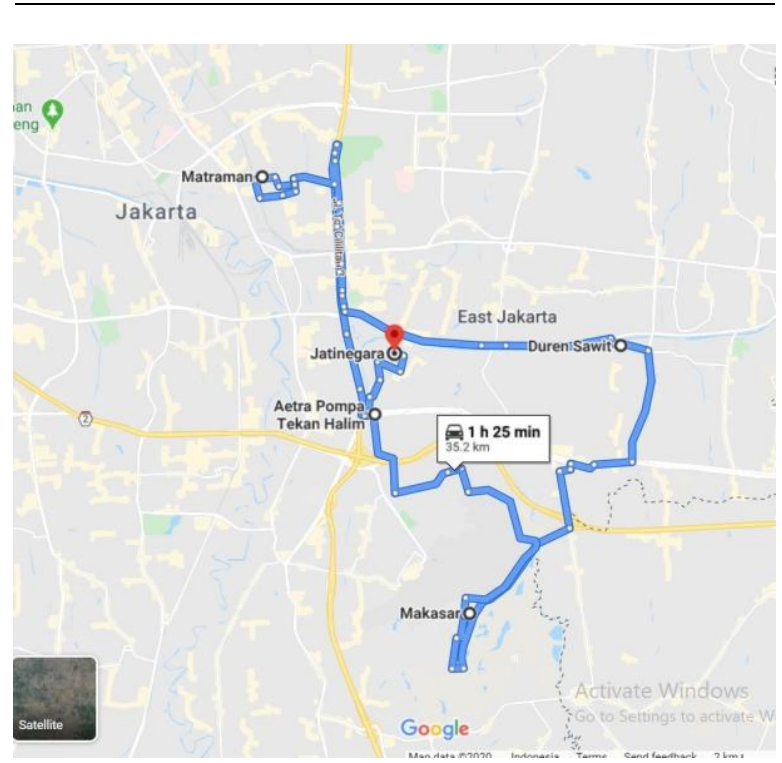

Gambar 7. Distribusi Tiap Booster Pump ke Tiap Kecamatan (PT AETRA) 

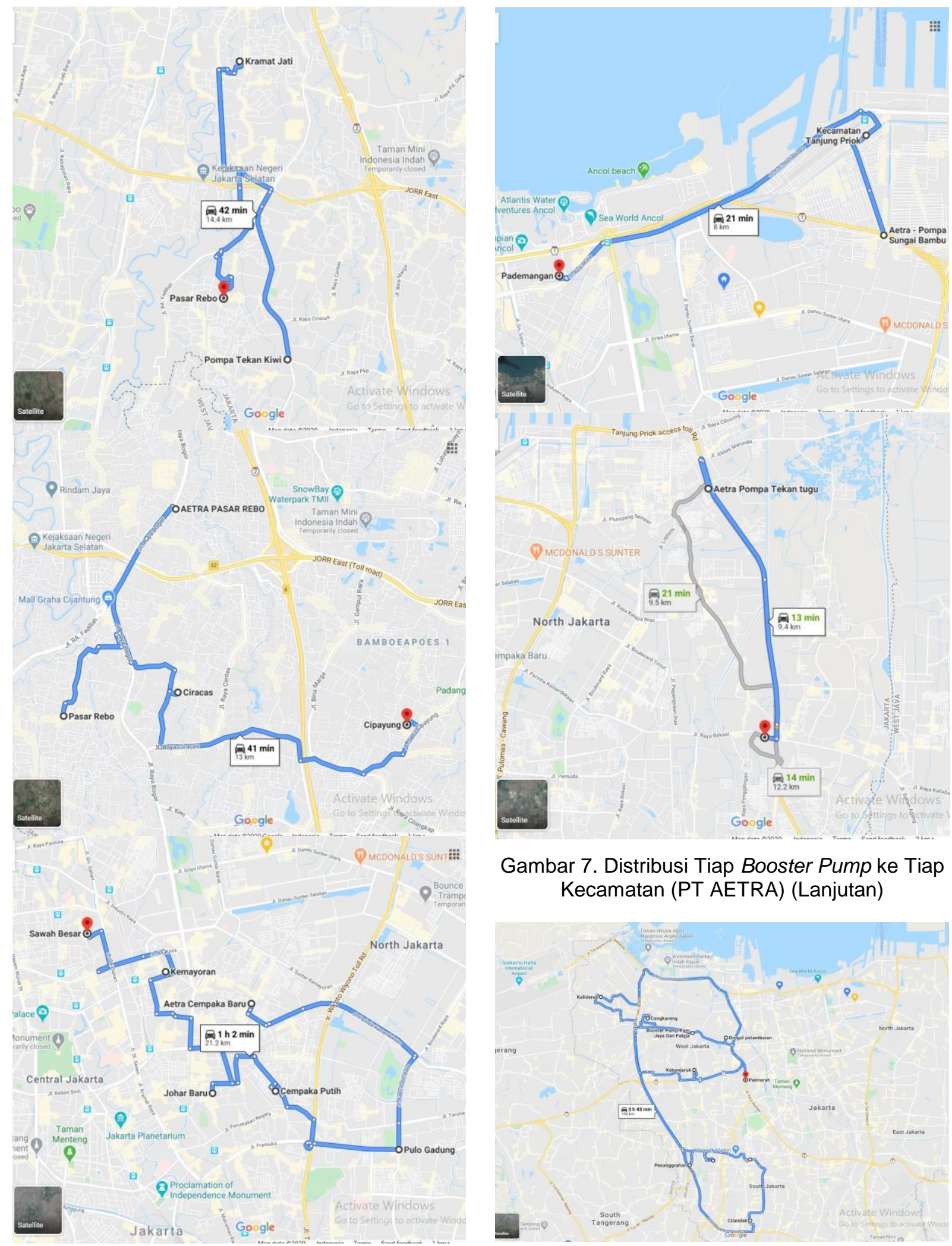

Gambar 7. Distribusi Tiap Booster Pump ke Tiap Kecamatan (PT AETRA) (Lanjutan)

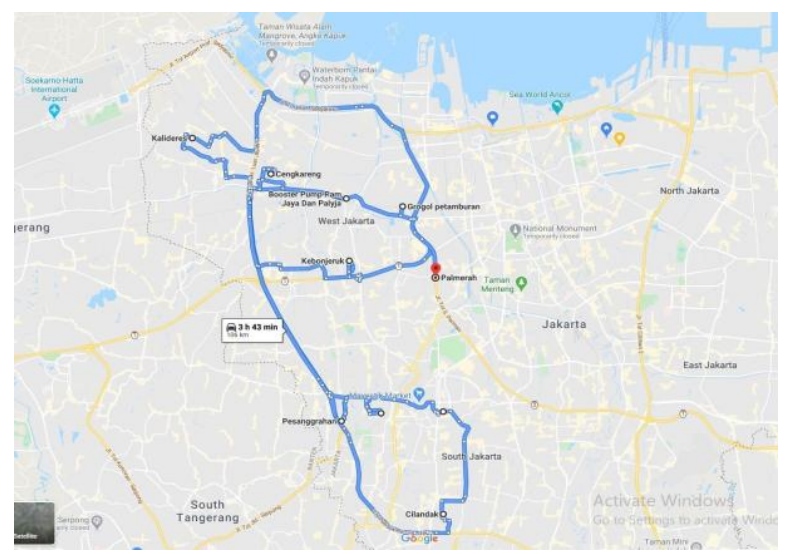

Gambar 8. Distribusi Tiap Booster Pump ke Tiap Kecamatan (PT AETRA) 


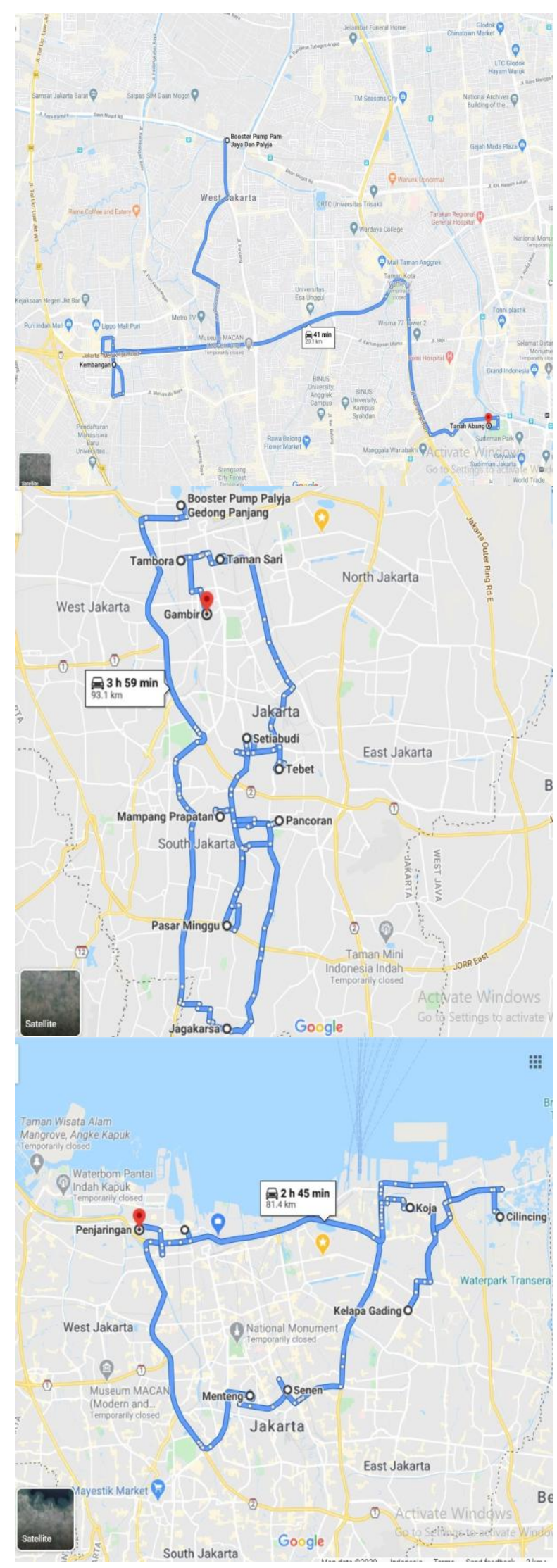

Gambar 8. Distribusi Tiap Booster Pump ke Tiap Kecamatan (PT AETRA) (Lanjutan)

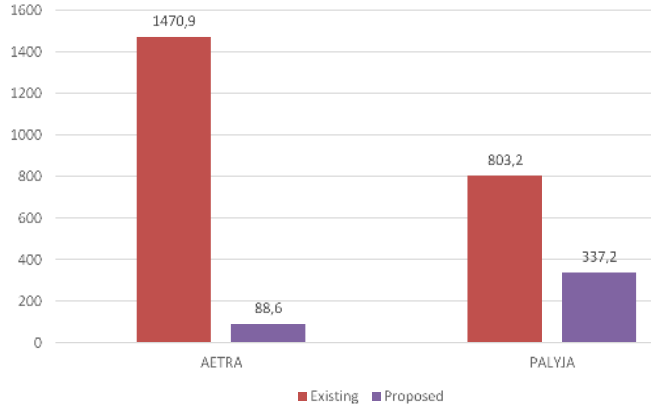

Gambar 9. Pengoptimalan Jarak (Km) pada PT. AETRA dan PT. PALYJA

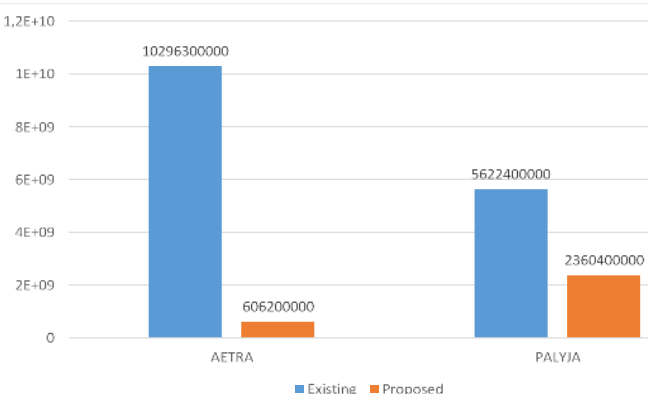

Gambar 10. Efisiensi Biaya (Rp.) pada PT. AETRA dan PT. PALYJA

Pengoptimalan jarak dengan menggunakan metode MST didapatkan efisiensi jarak yang cukup signifikan pada PT. AETRA maupun PT. PALYJA. PT. AETRA dapat dioptimalkan dari jarak $1470.9 \mathrm{Km}$ menjadi $86.6 \mathrm{Km}$, sedangkan PT. PALYJA dapat dioptimalkan dari jarak 803.2 $\mathrm{Km}$ menjadi $337.2 \mathrm{Km}$ (Gambar 9). Hasil pengoptimalan jarak dengan menggunakan metode MST berpengaruh pada efisiensi biaya pipa, didapatkan efisiensi biaya yang cukup signifikan pada PT. AETRA maupun PT. PALYJA. PT. AETRA dapat dioptimalkan dari biaya Rp. 10.296.300.000 menjadi Rp. 606.200.000, sedangkan PT. PALYJA dapat dioptimalkan dari biaya Rp. 5.622 .400 .000 menjadi Rp.2.360.400.000 (Gambar 10).

\section{KESIMPULAN}

Berdasarkan pengolahan data yang dilakukan, metode MST dapat meminimalkan panjang jaringan pipa air bersih untuk PT PAM Lyonaisse Jaya dan PT AETRA Air Jakarta sehingga dapat mengurangi biaya yang dikeluarkan. Biaya yang dikeluarkan untuk PT PAM Lyonaisse Jaya berkurang 2 kali lipat dan PT Aetra Air Jakarta 16 kali lipat lebih rendah dari semula dapat dilihat melalui Gambar 10 dan 11. Penelitian ini menggunakan asumsi yang sangat sederhana bahwa jarak berbanding lurus 
dengan biaya. Penelitian selanjutnya diharapkan dapat memperhitungkan debit air, konsumsi air per kecamatan dan kondisi pipa/instalasi di lapangan untuk untuk memperoleh pendekatan biaya distribusi.

\section{DAFTAR PUSTAKA}

Addini's, S. S. F., \& Fauzan, M. (2018). Penyelesaian Masalah Rute Terpendek Distribusi Kertas di CV. Margota Fancindo Yogyakarta Menggunakan Metode Nearest Neighbor dan Metode Saving Matrix. Jurnal Pendidikan Matematika Dan Sains, 7(3), 111. Retrieved from http://journal.student.uny.ac.id/ojs/ojs/index. php/math/article/view/11137.

Adrian, D., Syahrizal, \& Indrawan, I. (2014). Analisis Jaringan Sistem Distribusi Air Bersih Pada Komplek Perumahan PT Arun NGL Lhokseumawe. Jurnal Teknik Sipil USU, 3(2), 1-11. Retrieved from https://jurnal.usu.ac.id/index.php/jts/article/vi ew/7602.

Aetra. (2017). Laporan Tahunan AETRA 2017: Sinergi untuk Pelayanan yang Berkualitas. Jakarta. Retrieved from http://aetra.co.id/upload/AETRA2017\%20fin al3.pdf.

Akpan, N. P., \& Iwok, I. A. (2017). A minimum spanning tree approach of solving a transportation problem. International Journal of Mathematics and Statistics Invention, 5(3), 09-18. Retrieved from http://www.ijmsi.org/Papers/Volume.5.Issue. 3/B05030918.pdf.

Al Amin, M. B. (2011). Komputasi Analisis Hidraulika Jaringan Pipa Air Minum. Seminar Nasional Kebumian 2011 (pp. 318). UPN Veteran" Yogyakarta. Retrieved from http://repository.unsri.ac.id/8499/.

Anisah, R. R. (2016). Perancangan Rute Pendistribusian Produk Obat Dengan Menggunakan Algoritma Tabu Search Pada Vehicle Routing Problem With Time Window di PT XYZ Bandung. e-Proceeding of Engineering (pp. 2384-2391). Telkom University. Retrieved from https://openlibrary.telkomuniversity.ac.id/pu staka/files/116935/jurnal_eproc/perancanga n-rute-pendistribusian-produk-obat-denganmenggunakan-algoritma-tabu-search-padavehicle-routing-problem-with-time-windowdi-pt-xyz-bandung.pdf.

Anka, M. Z. A., Andrawina, L., \& Rendra, M. (2017). Usulan Rancangan Rute Transportasi Multi Trip untuk Meminimasi Biaya Transportasi dengan Heterogeneous Fleet dan Time Window menggunakan
Metode Algoritma Genetika di PT. XYZ. Journal Industrial Services, 3(1), 1-5. Retrieved from http://jurnal.untirta.ac.id/index.php/jiss/articl e/view/2056.

Aqidawati, E. F., Rahadian, N., Haqqoni, Z., Yuniaristanto, \& Sutopo, W. (2018). Optimasi Distribusi Semen PT. XYZ dengan Modifikasi Model Transportasi. Jurnal Rekayasa Sistem \& Industri (JRSI), 4(02), 187-191. https://doi.org/10.25124/jrsi.v4i02.288.

Arifuddin, Parung, H., \& Thaha, A. (2013). Analisis Kapasitas dan Pengembangan Jaringan Pipa Distribusi PDAM di Wilayah Pesisir Kecamatan Tallo, Kota Makassar. Universitas Hasanuddin. Retrieved from http://pasca.unhas.ac.id/jurnal/files/a04a00f 39256cae6318efa43215b0c73.pdf.

Brata, T. J. (2018). Sering Dilupakan, Ketersediaan Air di Jakarta Memprihatinkan. Retrieved from https://www.jawapos.com/ekonomi/21/03/20 18/sering-dilupakan-ketersediaan-air-dijakarta-memprihatinkan/.

Burek, P., Satoh, Y., Fischer, G., Kahil, M. T., Scherzer, A., Tramberend, S., ... Flörke, M. (2016). Water futures and solution-fast track initiative. WP-16-006. Retrieved from http://pure.iiasa.ac.at/id/eprint/13008/.

Chandra, A., \& Setiawan, B. (2018). Optimasi Jalur Distribusi dengan Metode Vehicle Routing Problem ( VRP ) Optimizing the Distribution Routes Using Vehicle Routing Problem ( VRP ) Method. Jurnal Manajemen Transportasi Dan Logistick, 05(02), 105-116. Retrieved from https://journal.itltrisakti.ac.id/index.php/jmtra nslog/article/view/233.

CV. Aneka Pratama. (2020). Harga Pipa HDPE SDR11 Pn 16. Retrieved from https://www.anekateknika.com/harga-pipahdpe-pn16-pipa-hdpe-sdr11-tahun2018.html.

DetikFinance (2019). Duh, Baru 72\% Wilayah RI yang Bisa Akses Air Bersih. Retrieved from https://finance.detik.com/infrastruktur/d4479084/duh-baru-72-wilayah-ri-yang-bisaakses-air-bersih.

Direktorat Jenderal Sumber Daya Air (2017). Review Rencana Strategis 2015 - 2019. Kementrian Pekerjaan Umum dan Perumahan Rakyat. Retrieved from https://www.pu.go.id/source/Renstra-20152019.pdf.

Fikri, D. A. (2018). Lebih dari 33,4 Juta Penduduk Indonesia Masih Kekurangan Air Bersih. Retrieved

from 
https://lifestyle.okezone.com/read/2018/11/2 2/481/1981405/lebih-dari-33-4-jutapenduduk-indonesia-masih-kekurangan-airbersih.

Guo, H., Liu, L., Chen, J., Xu, Y., \& Jie, X. (2017). Alzheimer Classification using a Minimum Spanning Tree of High-Order Functional Network on fMRI Dataset. Frontiers in Neuroscience, 11. https://doi.org/10.3389/fnins.2017.00639.

Gultom, E. R. (2017). Merefungsi Pengangkutan Laut Indonesia Melalui Tol Laut Untuk Pembangunan Ekonomi Indonesia Timur. Develop, 1(2), 1-12. https://doi.org/10.25139/dev.v1i2.381.

Guritno, T. (2019). PAM Jaya: 40 persen Warga Jakarta Belum Nikmati Air Bersih. Retrieved from

https://megapolitan.kompas.com/read/2019/ 03/22/13301601/pam-jaya-40-persenwarga-jakarta-belum-nikmati-air-bersih.

Hidayah, M. N., Andawayanti, U., \& Lufira, R. D. (2020). Penentuan Harga Air Bersih untuk Pengembangan Jaringan Distribusi Air Bersih di Kecamatan Wonoasri Kabupaten Madiun. Jurnal Mahasiswa Jurusan Teknik Pengairan, 3(2),1-4. Retrieved from http://pengairan.studentjournal.ub.ac.id/inde x.php/jmtp/article/view/539.

Hillier, F. S., \& Lieberman, G. J. (2010). Introduction to Operations Research (10th ed.). New York: McGraw-Hill Education. Retrieved from https://archive.org/details/IntroductionToOp erationsResearch10thEd2015/page/n9/mod e/2up.

Ikhsanudin, A. (2019). Aetra dan PAM Jaya Sepakati HoA Pengelolaan Air Jakarta. Retrieved from https://news.detik.com/berita/d-

4507952/aetra-dan-pam-jaya-sepakati-hoapengelolaan-air-jakarta.

Indonesia.go.id. (2019). Mengejar Pencapaian Akses $100 \%$ di 2019. Retrieved from https://www.indonesia.go.id/narasi/indonesi a-dalam-angka/ekonomi/mengejarpencapaian-akses-100-di-2019.

Indrawati, I., Eliyati, N., \& Lukowi, A. (2016). Penentuan Rute Optimal pada Pengangkutan Sampah di Kota Palembang dengan Menggunakan Metode Saving Matrix. Jurnal Penelitian Sains, 18(3), 105$110 . \quad$ Retrieved from http://ejurnal.mipa.unsri.ac.id/index.php/jps/ article/view/17.

lqbal, M. (2019). Mengerikan! Kelangkaan Absolut: 2040 Krisis Air di Pulau Jawa.
Retrieved

from

https://www.cnbcindonesia.com/news/2019

0520141416-4-73589/mengerikan-

kelangkaan-absolut-2040-krisis-air-di-pulaujawa.

Irwan, H., \& Yuniral. (2016). Optimasi Penjadwalan Produksi dengan Metode Transportasi. PROFIENSI, 4(2), 79-89. Retrieved from https://www.journal.unrika.ac.id/index.php/ju rnalprofisiensi/article/view/587.

Jono. (2014). Penentuan Jarak Optimal Guna Meminimalkan Baya Transportasi Menggunakan Metode Minimal Spanning Tree. Jurnal SimanteC, 4(1), 49-60. Retrieved from https://ecoentrepreneur.trunojoyo.ac.id/simantec/articl e/view/1346.

Kadir, N. P. (2020). Mewujudkan Layanan Air Minum Perpipaan. Retrieved from https://news.detik.com/kolom/d4849708/mewujudkan-layanan-air-minumperpipaan.

Kahfi. (2019). Begini Sejarah Pengelolaan Air dan Proses Swastanisasi di Jakarta. Retrieved from https://jakarta.bisnis.com/read/20190213/77 /888223/begini-sejarah-pengelolaan-airdan-proses-swastanisasi-di-jakarta.

Kementerian Pekerjaan Umum dan Perumahan Rakyat. (2015). Rencana Strategis 2015 $2019 . \quad$ Retrieved from https://www.pu.go.id/source/Renstra-20152019.pdf.

Kementerian Pekerjaan Umum dan Perumahan Rakyat Direktorat Jendral Sumber Daya Air. (2019). Majalah Air: Informasi Seputar Sumber Daya Air, 32-33. Retrieved from http://sda.pu.go.id/assets/uploads/bulletin/e 695d-majalah-air-jan-feb-2019-perpagesmin.pdf

Latifah, U., \& Sugiharti, E. (2015). Penerapan Algoritma Prim dan Kruskal pada Jaringan Distribusi Air PDAM Tirta Moedal Cabang Semarang Utara. UNNES Journal of Mathematics, 4(1). Retrieved from https://journal.unnes.ac.id/sju/index.php/ujm /article/view/7418.

Li, H., Mao, W., Zhang, A., \& Li, C. (2016). An Improved Distribution Network Reconfiguration Method based on Minimum Spanning Tree Algorithm and Heuristic Rules. International Journal of Electrical Power and Energy Systems, 82, 466-473. https://doi.org/10.1016/j.ijepes.2016.04.017.

Mekonnen, M. M., \& Hoekstra, A. Y. (2016). Four billion people facing severe water scarcity. 
Science Advances, 2(2), 1-7. https://doi.org/10.1126/sciadv.1500323.

Mosbah, M., Arif, S., Mohammedi, R. D., \& Hellal, A. (2017). Optimum Dynamic Distribution Network Reconfiguration using Minimum Spanning Tree Algorithm. In The 5th International Conference on Electrical Engineering - Boumerdes, ICEE-B 2017 (pp. 1-6). https://doi.org/10.1109/ICEEB.2017.8192170.

Muhammad, Bakhtiar, \& Rahmi, M. (2017). Penentuan Rute Transportasi Distribusi Sirup Untuk Meminimalkan Biaya. Malikussaleh Industrial Engineering Journal, 6(1), 10-15. Retrieved from https://www.journal.unimal.ac.id/miej/article/ view/152.

Munir, R. (2010). Matematika Diskrit. Bandung: Informatika. Retrieved from http://eprints.mercubuana-yogya.ac.id/469/.

Nurprihatin, F., Elnathan, R., Rumawan, R. E., \& Regina, T. (2019). A distribution strategy using a two-step optimization to maximize blood services considering stochastic travel times. IOP Conference Series: Materials Science and Engineering, 650(1). https://doi.org/10.1088/1757899X/650/1/012043.

Nurprihatin, F., Octa, A., Regina, T., Wijaya, T., Luin, J., \& Tannady, H. (2019). The Extension Analysis of Natural Gas Network Location- Routing Design through the Feasibility Study. Journal of Applied Research on Industrial Engineering, 6(2), 108-124. https://doi.org/10.21859/ijnr13021.

Nurprihatin, F., \& Tannady, H. (2018). An integrated transportation models and savings algorithm to minimize distribution costs. Proceeding of the 1st Asia Pacific Conference on Research in Industrial and Systems Engineering. Retrieved from https://www.researchgate.net/profile/Hendy _Tannady/publication/335231165_An_Integ rated_Transportation_Models_and_Savings _Algorithm_to_Minimize_Distribution_Costs //inks/5d59c6c-292851cb74c7601d8/ĀnIntegrated-Transportation-Models-andSavings-Algorithm-to-Minimize-DistributionCosts.pdf.

Palyja. (2017). Annual Report PALYJA 2017: Make it Happen Together. Jakarta. Retrieved from https://palyja.co.id/wpcontent/uploads/2019/01/PALYJAannualrep ort2017.pdf.

Peng Hou, Weihao Hu, \& Chen, Z. (2015). Offshore Wind Farm Cable Connection Configuration Optimization using Dynamic
Minimum Spanning Tree Algorithm. In 2015 50th International Universities Power Engineering Conference (UPEC) (pp. 1-6). IEEE. https://doi.org/10.1109/UPEC.2015.733989 6.

Pillai, A. C., Chick, J., Johanning, L., Khorasanchi, M., \& De Laleu, V. (2015). Offshore Wind Farm Electrical Cable Layout Optimization. Engineering Optimization, 47(12), 1689-1708. https://doi.org/10.1080/0305215X.2014.992 892.

Pratama, A. P., Sumarno, \& Darmaji. (2013). Penggunaan Algoritma Kruskal Dalam Jaringan Pipa Air Minum Kecamatan Nganjuk Kabupaten Nganjuk. Jurnal Sains Dan Seni Pomits, 1(1), 1-6. Retrieved from http://digilib.its.ac.id/public/ITS-paper32489-1209100040-paper.pdf.

PT Aetra Air Jakarta. (2019a). Bagaimana Cara Jadi Pelanggan Aetra. Retrieved from https://www.aetra.co.id/info_pelanggan.

PT Aetra Air Jakarta. (2019b). Capaian Kinerja PT Aetra Air Jakarta Sampai 2018. Retrieved from https://www.aetra.co.id/berita/detail/214/CA PAIAN-KINERJA-PT-AETRA-AIRJAKARTA-SAMPAI-2018.

PT Aetra Air Jakarta. (2019c). Profil Perusahaan AETRA. Retrieved from https://www.aetra.co.id/profil_perusahaan.

PT PAM Lyonnaise Jaya. (2019a). Lembar Fakta PALYJA 2018. Jakarta. Retrieved from https://palyja.co.id/id/lembar-fakta-2/.

PT PAM Lyonnaise Jaya. (2019b). Sejarah PALYJA. Retrieved from https://palyja.co.id/id/sejarah-palyja/.

Rembulan, G. D., \& Nurprihatin, F. (2019). Desain Jaringan Distribusi Raskin dengan Fuzzy Analytical Network Process untuk Meminimalkan Biaya Transportasi. Prosiding Seminar Nasional Pendidikan Dan Teknologi Kejuruan, 263-268. Retrieved from http://seminars.unj.ac.id/snptk2019/wpcontent/uploads/2019/06/BUKU-SEMINARSNPTK-2019_Final_UPDATE.pdf.

Ridha, M. R., Abdi, C., \& Mahyudin, R. P. (2016). Studi Optimasi Rute Pengangkutan Sampah Kota Marabahan Dengan Sistem Informasi Geografis. Jukung, 2(2), 38-51. http://dx.doi.org/10.20527/jukung.v2i2.2310.

Riswan. (2018). Penentuan Jarak Minimum dalam Suatu Jaringan Listrik dengan Algoritma Prim dan QM for Windows (Studi Kasus Pada Perumahan Nelayan di Kota Palopo). Al-Khwarizmi: Jurnal Pendidikan 
Matematika Dan Ilmu Pengetahuan Alam, 6(1), $\quad$ 77-88. https://doi.org/10.24256/jpmipa.v6i1.460.

Rizki, S. (2012). Penerapan Teori Graf Untuk Menyelesaikan Masalah Minimum Spanning Tree (MST) Menggunakan Algoritma Kruskal. AKSIOMA Journal of Mathematics Education, 1(2). https://doi.org/10.24127/ajpm.v1i2.68.

Said, S. (2019). Perluas Cakupan Layanan Air Bersih, Perumda Air Minum Tirta Raharja Gandeng Swasta. Retrieved from https://jabar.sindonews.com/berita/9268/1/p erluas-cakupan-layanan-air-bersihperumda-air-minum-tirta-raharja-gandengswasta.

Sarjono, H. (2014). Determination of Best Route to Minimize Transportation Costs Using Nearest Neighbor Procedure. Applied Mathematical Sciences, 8(62). Retrieved from

https://research.binus.ac.id/publication/7DC 21113-DB1B-477F-8492-

076931314F5D/determination-of-best-routeto-minimize-transportation-costs-usingnearest-neighbor-procedure/.

Setiawan, H. D., Haribowo, R., \& Ismoyo, M. J. (2019). Perencanaan Sistem Jaringan Pipa Distribusi Air Bersih di Desa Tegalsari Kecamatan Kepanjen Kabupaten Malang. Jurnal Mahasiswa Jurusan Teknik Pengairan, 2(2), 1-8. Retrieved from http://pengairan.studentjournal.ub.ac.id/inde x.php/jmtp/article/view/404.

Setiawan, M. H., Imrona, M., \& Murdiansyah, D. T. (2017). Optimasi Rute Angkutan Kota Secara Simultan Menggunakan Algoritma Exhaustive Search (Studi Kasus Sepuluh Trayek Kota Bandung). Indonesian Journal of Computing, 2, 47-54. https://doi.org/10.21108/indojc.2017.22.178.

Setyono, H. S., \& Prayogo, T. B. (2018). Analisis Kelayakan Ekonomi untuk Penentuan Harga Air pada Jaringan Penyediaan Air Bersih di Desa Kertosari Kecamatan Purwosari Kabupaten Pasuruan. Jurnal Mahasiswa Jurusan Teknik Pengairan, 1(2). Retrieved from http://pengairan.studentjournal.ub.ac.id/inde x.php/jmtp/article/view/58.

SM, A. I., Ekawati, R., \& Febriana, N. (2017). Optimalisasi Rute Distribusi Air Minum Quelle Dengan Algoritma Clarke \&amp; Wright Saving Dan Model Vehicle Routing Problem. In Seminar Nasional Inovasi dan Aplikasi Teknologi di Industri (pp. 1-7). Retrieved https://ejournal.itn.ac.id/index.php/seniati/art icle/view/1573.

Sutikno, Rispiningtati, \& Prayogo, T. B. (2014). Studi Kelayakan Ekonomi Sistem Jaringan Air Bersih Hipam Kelurahan Dadaprejo Kecamatan Junrejo Kota Batu. Jurnal Pengairan, 248-258. Retrieved from https://jurnalpengairan.ub.ac.id/index.php/jt p/article/view/297.

Wahyu, R., Samanhudi, D., \& Akmal. (2018). Penentuan Rute Distribusi Produk Gas untuk Meminimumkan Biaya Distribusi dengan Metode Clarke \& Wright Saving di CV. Surya Inti Gas. Journal of Industrial Engineering and Management, 13(01), 8491.

https://doi.org/10.33005/tekmapro.v13i1.64.

Wattimena, A. Z., \& Lawalata, S. (2013). Aplikasi Algoritma Kruskal Dalam Pengoptimalan Panjang Pipa. Jurnal Barekeng, 7(2), 1318. Retrieved from https://ojs3.unpatti.ac.id/index.php/barekeng /article/view/251.

Windarto, A. P., \& Sudirman. (2018). Penerapan Algoritma Semut dalam Penentuan Distribusi Jalur Pipa Pengolahan Air Bersih. Jurnal Sistem Informasi Bisnis, 02, 123132.

https://doi.org/10.21456/vol8iss2pp123-132.

Wulandari, D. A. R., \& Arifin, F. N. (2018). Penentuan Rute Terpendek Jalur Distribusi Air Artesis Menggunakan Kruskal. J-SAKTI (Jurnal Sains Komputer Dan Informatika), 2(2), 121. https://doi.org/10.30645/jsakti.v2i2.72. 